\title{
Long term carbamazepine therapy induced acute lymphoblastic leukemia
}

\author{
Chhaya Goyal ${ }^{\mathrm{a}, \mathrm{b}}$, Virendra Bhandari ${ }^{\mathrm{c}}$, Mohammad Rafi ${ }^{\mathrm{d}}$
}

\begin{abstract}
${ }^{a}$ Professor \& Head, Department of Pharmacology, Sri Aurobindo Medical College \& PG Institute, Indore (M.P.), India,

${ }^{\mathrm{b}}$ Coordinator, ADR Monitoring Centre, Department of Pharmacology, Sri Aurobindo Medical College \& PG Institute, Indore (M.P.), India,

${ }^{c}$ Professor, Department of Radiotherapy, Sri Aurobindo Medical College \& PG Institute, Indore (M.P.), India,

${ }^{\mathrm{d}}$ Technical Associate, ADR Monitoring Centre, Department of Pharmacology, Sri Aurobindo Medical College \& PG Institute, Indore (M.P.), India
\end{abstract}

Received: 30 January 2013

Accepted: 20 March 2013

\section{*Correspondence to: \\ Dr. Virendra Bhandari, \\ Email: virencancer@yahoo.co.in}

(C) 2013 Goyal C et al. This is an open-access article distributed under the terms of the Creative Commons Attribution License, which permits unrestricted use, distribution, and reproduction in any medium, provided the original work is properly cited.

\begin{abstract}
Carbamazepine is a commonly used antiepileptic drug. Apart from the neurological side-effects, hematological side-effects in form of aplastic anemia and agranulocytosis are well-documented. We report an unusual case of Acute Lymphoblastic Leukemia (ALL) associated with the long term use of carbamazepine. On hospitalization, the drug carbamazepine was stopped and after confirmation of the diagnosis, patient was started on standard treatment for ALL.
\end{abstract}

Keywords: Carbamazepine, Antiepileptic, Acute lymphoblastic leukemia

\section{INTRODUCTION}

Carbamazepine is an iminostilbene derivative and chemically related to the tricyclic antidepressants, mainly used as an antiepileptic drug in partial and tonic-clonic seizures, also used in trigeminal neuralgia and bipolar affective disorder. ${ }^{1}$ Carbamazepine is known for its neurological side-effects, however even forty years earlier a case of aplastic anemia was reported due to Carbamazepine. ${ }^{2}$ Leucopenia and thrombocytopenia were reported in $2 \%$ of patients, while aplastic anemia in 0.8 $\% .^{3}$

\section{CASE REPORT}

A 22 years old male patient was hospitalized with complaints of excessive weakness and giddiness since two months. He also had pain and swelling of right ankle joint following injury. His complete blood count report showed hemoglobin $4.6 \mathrm{gm} \%$ and total leucocytes count of $20,700 / \mathrm{mm}^{3}$ with $66 \%$ immature cells of lymphoid series. Platelet Count was only $10,000 / \mathrm{mm}^{3}$. Peripheral smear examination showed normocytic normochromic RBCs, leucocytosis with more than $80 \%$ large blast cells with thin rim of cytoplasm 1-2 nucleoli, smudged cells, with markedly reduced platelets suggestive of ALL. Bone marrow analysis revealed hypercellularity and was replaced by monomorphic round cells showing scanty cytoplasm and hyperchromatic nucleus, hand mirror cells were seen (lymphoblasts 95\%). The erythroid series, myeloid series and megakaryocytes were suppressed confirming the diagnosis of Acute Lymphoblastic Leukemia (ALL). He had multiple enlarged submental, submandibular and left upper cervical lymph nodes which were firm and mobile.

Patient had history of seizures at the age of 10 years, for that he was taking carbamazepine tablets $(200 \mathrm{mg}$ twice a day) since last 12 years. There is no history of other concomitant medications and no reports of other investigations in this time span. On $1^{\text {st }}$ day of hospitalization, the suspected drug carbamazepine was withdrawn. 
Patient diagnosed with ALL was treated with vincristine $2 \mathrm{mg}$, doxorubicin 50mg and prednisolone $40 \mathrm{mg} /$ day with allopurinol on the $3^{\text {rd }}$ day of hospitalization. He was transfused multiple units of whole blood and platelets as the blood reports revealed worsening of patient's condition. His last complete blood count report was hemoglobin $2.0 \mathrm{gm} \%$, total leucocytes count of $200 / \mathrm{mm}^{3}$ and platelet count 7000 after which on the $9^{\text {th }}$ day of hospitalization, the patient died.

\section{DISCUSSION}

In preclinical studies, the drug was found to have carcinogenic potential. Rats who were treated with carbamazepine for 2 years, found to have increased incidence of tumors of liver. ${ }^{4}$ Four cases have been reported to have developed pure red cell aplasia following carbamazepine in published literature to date. ${ }^{5,6}$ There are very rare cases published in the literature, not fully suggestive of ALL-carbamazepine causal relationship but similar reactions giving a picture of Pseudo-Leukemic syndrome have been seen. Three epileptic children who had been treated with antiepileptic drug including carbamazepine were eventually found to be suffering from ALL. ${ }^{7}$ Two cases, highlight the wide variability of the bone marrow, which may show pseudohypercellularity with disappearance of neutrophils and excess of immature cells (myeloblasts and promyelocytes), thus mimicking the features of acute myeloid leukemia. ${ }^{8}$ The changes in WBC that occurred with Carbamazepine may be the probable cause of leucocytosis. ${ }^{9}$ While some of these cases represent some coincidence, we should keep ALL in mind when treating children with carbamazepine and haematological monitoring should be done regularly.

\section{CONCLUSION}

This case illustrates an unexpected outcome that the bone marrow could not regenerate after suppression probably due to a long term use of carbamazepine. The hematologic adverse effects of carbamazepine, although not common, should be borne in mind due to the serious, prolonged and sometimes even fatal consequences. It may be pertinent to explain the neurologic, hematologic, hypersensitivity or dermatologic side-effects of carbamazepine, at the time of initiation of therapy; and advise patients for regular monitoring of blood counts.

\section{Funding: No funding sources \\ Competing interests: No competing interests \\ Ethical approval: Not required}

\section{REFERENCES}

1. McNamara JO. Pharmacotherapy of the Epilepsies. In: Brunton LL, Lazo JS, Parker KL, editors. The Pharmacological Basis of Therapeutics. 11 th ed. New Delhi: McGraw Hill; 2006. p. 511.

2. Gayford JJ, Redpath TH. The side-effects of carbamazepine. Proc Roy Soc Med 1969;62:11-2.

3. Hart RG, Easton JD, Carbamazepine and hematological monitoring. Ann Neurol 1982;11:309-12.

4. Yamaoka M, Imai K, Sunahara M, Fukuyama Y, Osawa M. Treatment of Three Children Who Developed Acute Lymphoblastic Leukemia with Carbamazepine. Journal of Tokyo Women's Medical University 2000;70:E122-6. Available at http://sciencelinks.jp/jeast/display.php?id=000020002100A0743352. Accessed on 20 December 2012.

5. Chandra Sekhar C, Reddi VR, Srinivas B, Naik KR. J Assoc Physicians India 1998;46:655-6.

6. Marwaha RK, Bansal D, Trehan A, Marwaha N, Varma N. Clinico-haematological profile of pure red cell aplasia in children. $\mathbf{J}$ Trop Pediatr 2002;48:113-6.

7. Medsafe [Internet]. Wellington: New Zealand Medicines and Medical Devices Safety Authority. Available http://www.medsafe.govt.nz/profs/datasheet/t/Tegre toltabsyrup.pdf. Accessed on 20 December 2012.

8. Banfi L, Ceppi M, Colzani M, Guzzini F, Morena R, Novati P. Carbamazepine-induced agranulocytosis. Recenti Prog Med 1998;89:510-3.

9. Murphy JE, Stewart RB, Springer PK. Carbamazepine-induced leukocytosis. Am J Hosp Pharm 1980;37:550-2.

doi:10.5455/2319-2003.ijbcp20130320

Cite this article as: Goyal C, Bhandari V, Rafi M. Long term carbamazepine therapy induced acute lymphoblastic leukemia. Int J Basic Clin Pharmacol 2013;2:222-3. 